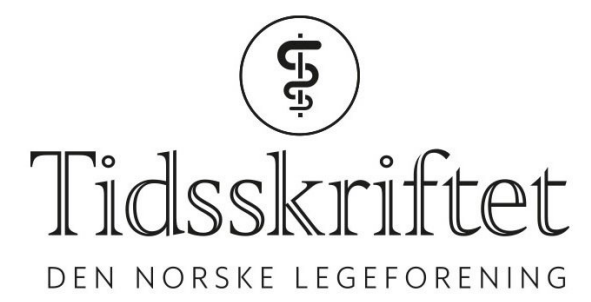

\title{
Får mennesket plass i pakken?
}

LEDER

\section{METTE BREKKE}

E-post: mette.brekke@medisin.uio.no Mette Brekke er spesialist i allmennmedisin, fastlege ved Kurbadet legesenter og professor i allmennmedisin ved Universitetet i Oslo. Forfatter har fylt ut ICMJE-skjemaet og oppgir ingen interessekonflikter.

Pakkeforløp i psykiatrien utfordrer fastlegens pasientsentrerte tilnærming.

Nå er pakkeforløpene i psykisk helsevern her. Tre overordnede pakkeforløp ble implementert fra 1. januar i år, etter en del debatt i forkant (1-4): Pakkeforløp for utredning og behandling i psykisk helsevern, ett for voksne og ett for barn, samt pakkeforl $\emptyset p$ for psykisk helse og rus. Bak disse ligger fem målsettinger: Økt brukermedvirkning/-tilfredshet; sammenhengende og koordinerte pasientforløp; kutt i unødvendig ventetid; likeverdig tilbud over hele landet og bedre ivaretakelse av somatikk og levevaner (5). Disse overordnede godordene konkretiseres slik: Det skal lages en utredningsplan som skal gjennomføres i løpet av seks uker og som pasienten skal få kopi av. Et eventuelt avslag på behandling skal begrunnes. En "prioriteringsveileder» angir veiledende frister for å starte utredning ved ulike tilstander - f.eks. én uke ved bipolar lidelse type $1 \mathrm{i}$ ustabil fase.

En slik forutsigbarhet i utredning og ventetid innebærer et kvalitetsløft i forhold til dagens praksis. Mens kreftpakkeforløpene er rene ventetidsgarantier, skal neste fase av pakkeforløp i psykisk helsevern også omfatte selve behandlingen ved enkelte diagnoser. Vi får egne utrednings- og behandlingspakker for tvangslidelser, spiseforstyrrelser hos barn og unge og psykoseutvikling hos barn og unge. Om mer hyppige diagnoser som angst og depresjon også skal omfattes, blir så vidt jeg vet fortsatt diskutert.

Det melder seg flere bekymringer fra en fastleges ståsted. Psykiske plager og lidelser er uhyre vanlig i befolkningen og dermed også blant fastlegenes pasienter. I en norsk studie basert på direkte observasjon fant man at et psykisk problem ble tatt opp i en firedel av konsultasjonene (6). De aller fleste av disse pasientene kommer aldri i kontakt med annenlinjetjenesten - de utredes og følges opp hos fastlegen, i likhet med andre pasienter med vanlige plager og sykdommer. Vil en effekt av pakkeforløpene bli at både fastlege, pasient og pårørende oftere kommer til å tenke på henvisning som en mulighet? Hvis pasienten har angst/depresjon/tvangslidelse og det finnes et pakkeforløp for angst/depresjon/tvangslidelse, hvorfor ikke bruke det? Veilederens definisjon av alvorlighetsgrad levner ubegrensede muligheter for skjønn (5). I dagens rettighetsorienterte samfunn vil pasienten selvsagt ha det best mulige. Mange fastleger opplever allerede press om henvisning, ikke bare fra pasienter, men fra etater som Nav og barnevernstjenesten, der terapi kan synes å være svaret på de fleste spørsmål. Selv med en tenkt dobling - eller også en tre- eller femdobling - av henvisningsfrekvensen, vil fastlegen 
fortsatt selv ta seg av flertallet av pasienter med psykiske plager. Men for annenlinjetjenesten vil en slik økning antagelig være umulig å håndtere, særlig innen pakkeforløpenes tidsfrister.

Vil pakkeforløpene føre til en mer algoritmebasert og mindre pasientsentrert allmennmedisin? Fastlegekonsultasjonen er den eneste legetjenesten der fokus helt og fullt defineres ut fra pasientens symptomer, bekymringer og forventninger (7). Vil det bare være de symptomene som passer inn i forløpsveilederen som er av interesse? Det hevdes at livssmerte i vid forstand ligger til grunn for ca. halvparten av konsultasjonene i allmennpraksis (8) og at fastlegens jobb, hver dag, handler om å hjelpe lidende og kriserammede mennesker med å håndtere sine liv. Skal denne kompetansen bygges ned til fordel for å gjenkjenne algoritmer? For vi kan vel neppe vente oss et pakkeforløp for livssmerte?

Variasjon i annenlinjens behandling av pasienter innen samme diagnosekategori er en av begrunnelsene for pakkeforløpene. Men er denne variasjonen et problem? Eller er variasjonen begrunnet $i$ at pasienter trenger ulike og individuelle tilnærminger? Er kunnskapsgrunnlaget i psykiatrien sterkt nok til å forsvare økt diagnosebasert standardisering av utredning og behandling - kan man si at «angst er angst er angst»? Helsemyndighetene påpeker i andre sammenhenger at individbasert, brukerorientert og individuell behandling er ønskelig. Dette er fornuftig, også fordi vi vet fra behandlingsforskning at mange ulike tilnærminger kan være like effektive. Det er ikke lett å forstå hvordan kravet om økt standardisering kan bidra i en slik retning og hvordan disse temmelig ulike føringene kan forenes. Hva med dem som ikke passer inn? Skal de nedprioriteres? Det følger ingen $\emptyset$ kte ressurser med pasientenes styrkede rettigheter. Man kan frykte at annenlinjens innsats blir flyttet fra faglige vurderinger og behandling over på tung, tidkrevende administrasjon og økt byråkrati.

\section{LITTERATUR: \\ 1. Lundevall S. Pakkeforløp ved psykiske sykdommer? Tidsskr Nor Legeforen 2015; 135: 2129. [PubMed][CrossRef]}

2. Aarre TF. Korthuset som ramlar i psykiatrien. Vårt land 16.9.2015.

http://www.verdidebatt.no/innlegg/11598453(30.11.2018).

3. Vogt H, Pahle A. Likeverd på samlebånd. Morgenbladet 11.9.2015.

https://morgenbladet.no/ideer/2015/o9/likeverd-pa-samleband (30.11.2018).

4. Vogt H. Samleside om debatten om pakkeforløp i psykiatri.

https://henrikvogt.com/2015/o9/21/dette-er-en-samleside-for-debatten-om-pakkeforlop-i-psykiatri/ (30.11.2018)

5. Helsedirektoratet. Pakkeforløp for psykisk helse og rus.

https://helsedirektoratet.no/folkehelse/psykisk-helse-og-rus/pakkeforlop-for-psykisk-helse-og-rus (30.11.2018).

6. Bjørland E, Brekke M. What do patients bring up in consultations? An observational study in general practice. Scand J Prim Health Care 2015;33: 206-11. [PubMed][CrossRef]

7. Brown J, Stewart M, McCracken E et al. The patient-centred clinical method. 2. Definition and application. Fam Pract 1986; 3: 75-9. [PubMed][CrossRef]

8. Håndbok for fastlegeordningen. Trønderopprøret, 2018: 26. http://www.flo2o.no/handboka/ (30.11.2018).

Publisert: 21. januar 2019. Tidsskr Nor Legeforen. DOI: 10.4045/tidsskr.18.0884

(C) Tidsskrift for Den norske legeforening 2020. Lastet ned fra tidsskriftet.no 